Michał Rydlewski

\title{
WSZYSCY JESTEŚMY WYMYŚLENI
}

\author{
Nawet kłamiac - a składał się $z$ nieskończoności \\ małych, czasem parszywych, czasem wspaniałych \\ czasem bezsensownych, czasem ślicznych kłamstw- \\ zawsze przekazywat jakass prawde. \\ Nieważna prawdę. Potrzebna prawdę.
}

Leopold Tyrmand (cyt. za Hłasko 1998)

\section{Dlaczego wciąż czytamy te same książki?}

Wracam co jakiś czas do książek Marka Hłaski, tak jak ktoś, kto wraca do swojego obrazu sprzed lat i nie rozpoznaje w nim siebie samego. Podobnie jak introspekcja jest iluzja, co przekonywajaco pokazał „późny” Wittgenstein (Gurczyńska-Sady 2013: 20-25), tak pod wpływem naszego nastawienia (wiedzy, doświadczeń, oczekiwań) zmienia się sposób, w jaki czytamy książki, które kiedyś już raz się przeczytało, nie odnajdując w nich tego, co - jak nam się wydaje - było tam wcześniej.

W „Książkach. Magazynie do czytania”, dodatku do „Gazety Wyborczej" z grudnia 2012 roku, Wojciech Nowicki w artykule pt. Chwała pótkownikom zastanawia się nad fenomenem wielokrotnej lektury: powrotu do tych samych ksiażek, ponownego ich czytania. Nowicki przywołuje kilku anglojęzycznych badaczy analizujących owa praktykę $z$ perspektywy literaturoznawczej. Uświadomili mi oni, że ja, antyesencjalista, pilny czytelnik Stanleya Fisha („nie ma tekstu, sa tylko interpretacje”) (por. Fish 2002) i „późnego” Wittgensteina („zmiana aspektu”) (por. Wittgenstein 2011), okazałem 
się naiwny sądząc, że czytamy zawsze tę sama książkę. „Prawdziwy sekret wielokrotnej lektury jest prosty - trafnie zauważa Verlyn Klinkenborg - jest ona niemożliwa. Bohaterowie ksiazżek pozostaja ci sami, słowa nie ulegaja zmianie, lecz czytelnik zmienia się nieustannie" (cyt. za Nowicki 2012: 66). W innym miejscu Klinkenborg wyznaje zaś: „Zawsze podziwiałem moich przyjaciół, którzy wiele czytają. Niektórzy z nich szczyca się nawet tym, że nigdy nie czytają tej samej książki dwukrotnie. Sam nieomal rok spędziłem w czytelni British Museum, w bieżącej lekturze odkrywając tytuł następnej. Jednak w głębi serca wolę wracać do tych samych książek. Sens czytania tak wielu tytułów polegał na tym, żeby znaleźć ksiaż̇ki, które miałbym ochotę czytać wciąż na nowo" (Tamże: 66).

Podoba mi się powyższa myśl, mówiąca o tym, że czytamy wiele tylko po to, żeby znaleźć takie książki, które można czytać powtórnie. Jakiż sens mają więc potężne biblioteki gromadzone przez nas przez lata, jeśli - koniec końców - księgozbiór powinno się ograniczyć do kilku, kilkunastu książek czytanych wciąż od nowa? Nie sądźmy zatem zbyt pochopnie tych, którzy na półce mają tylko jedną ksiaż̇ę.

Sytuując swoje rozważania w kontekście wypowiedzi Klinkenborga, chciałbym je potraktować jako próbę rozstrzygnięcia zasadniczego dylematu: dlaczego wracam do tych samych książek, dlaczego wciąż mam ochotę czytać - ponownie i na różne sposoby - te, a nie inne lektury? Sposób, jaki przyjmuję za obowiązujący w moich poszukiwaniach mieścić się będzie w ramach klucza kulturoznawczo-filozoficznego, który, o ile wiem, nigdy nie był aplikowany do będącej dla mnie zasadniczym punktem odniesienia twórczości Marka Hłaski. Wybór ten ma swoje uzasadnienie nie tylko w tym, że kulturoznawczo-filozoficzny „styl myślowy” okazuje się cenny poznawczo (mówi nam wiele o literaturze jako dziedzinie kultury oraz kulturze jako takiej), lecz wypowiada także coś ważnego o piszacym te słowa; motyw ten rozwinę w dalszych partiach artykułu.

\section{Marek Hłasko - pisarz wybitny a metafora „prawdziwego zmyślenia"}

Marka Hłaskę uznaję za jednego $z$ najwybitniejszych polskich pisarzy drugiej połowy XX wieku. To pisarz nad wyraz ciekawy, mówiący wiele odkrywczych rzeczy, w tym dotyczacych kwestii literatury jako miejsca autokreacji tożsamości oraz przeplatania się 
fikcji i rzeczywistości. Przykładem oryginalności jego podejścia jest m.in. stosowanie metafory „prawdziwego zmyślenia”. Choć wielu pisarzy, nawet tych postrzeganych jako zdolniejszych od Marka Hłaski, miało zbliżone intuicje odnośnie do motywu „prawdziwego zmyślenia”, to ostatecznie żaden $z$ nich go użył podobnego, genialnego w swej prostocie i wymowie, sformułowania co autor Pięknych dwudziestoletnich.

Powyższa opinia może budzić wątpliwości, wynikające $z$ faktu, iż Hłasko jest dziś twórca nie tylko mocno zapomnianym (jeśli już się czyta coś Hłaskowskiego, to sa to raczej opowiadania), ale także, w dużej mierze, zbanalizowanym. Kiedy w dyskusjach akademickich przyznaję się do swoich sympatii i upodobań literackich, odnoszę wrażenie, bazując na reakcjach moich kolegów, że Hłasko nie cieszy się zbyt wielkim poważaniem pośród elit intelektualnych. Tak czy inaczej, za znacząca należy uznać sytuację braku pogłębionych analiz dzieł Hłaskowskich; poza niewielka - powiedziałbym: wstępną - pracą Jana Galanta (1996), próżno szukać tego rodzaju opracowań. Mój tekst został przygotowany z zamysłem wypełnienia, choćby w niewielkim, przyczynkarskim stopniu, luki na tym polu.

Owo zbanalizowanie powstałego przede wszystkim poza Polska dorobku Marka Hłaski, przejawia się m.in. w braku godnego uwagi namysłu nad metafora „prawdziwego zmyślenia”, ściślej - w traktowaniu jej jako swoistej literackiej sztuczki, bądź też wymysłu mitomana, za którego zreszta autor Pierwszego kroku $w$ chmurach uchodzi w kręgu szerszej publiczności, i - niestety - nie tylko jej ${ }^{1}$.

Takiego zabiegu dokonuje np. Adam Chmielewski, wrocławski profesor filozofii. Podczas pobytu w Stanach Zjednoczonych Chmielewski spotkał wiele osób znających Marka Hłaskę, zrobił też z nimi wywiady, opublikowane następnie w czasopiśmie „Odra” (por. Chmielewski 1993a: 62-69, 1993b: 73-79). „Na studiach poznałem ludzi, którzy mieli kontakt z Hłaską i zobaczyłem go bez literackiej maski” - czytamy u Chmielewskiego. Dodaje on: „Owe spotkania

${ }^{1}$ Na okładce Pieknych dwudziestoletnich wydanych w kolekcji „Polska literatura współczesna” biblioteki tygodnika „Polityka” czytamy, że (1) to książka „nie tylko autobiograficzna" (to nie jest książka autobiograficzna), że (2) wykreowała ona obraz autora jako polskiego „buntownika bez powodu” (Hłasko miał powód: był nim ustrój komunistyczny), wreszcie, że (3) określenie „piękni dwudziestoletni” weszło na trwałe do języka polskiego (może i tak, ale nie zawsze pamięta się o tym, że Hłasko nie odnosi tego zwrotu do siebie, gdyż to nie on jest tytułowym „pięknym dwudziestoletnim" - reprezentantem nowego, nadchodzącego pokolenia). Niestety, tak właśnie rodzi się banalizacja, operowanie kliszami i porównaniami ignorującymi istnienie często niewspółmiernych kontekstów. 
spisałem i opublikowałem, a te spotkania wiodły do następnych spotkań. To prawda, że jego optymistyczny mit okazał się całkowicie zmyślony, ale nawet tego Marek Hłasko skutecznie bronił, wprowadzajac w tej powiastce [Pięknych dwudziestoletnich - przyp. M.R.] ideę literatury jako prawdziwego zmyślenia" (Czytamy w Polsce... 2011). Jeśli zaakceptować takie ujęcie metafory „prawdziwego zmyślenia”, nie byłoby chyba sensu, żeby pisać cokolwiek więcej: jawi się nam ona jako czysto retoryczny chwyt, majacy usprawiedliwiać liczne konfabulacje i kłamstwa autora Bazy ludzi umarłych, któremu Adam Chmielewski - jako człowiekowi - wystawia surowa i krytyczna notę, przy okazji nazbyt chyba jednostronna.

Moja propozycja idzie w inna stronę. Chciałbym bowiem spojrzeć na Hłaskowską metaforę „prawdziwego zmyślenia” jako trop niezmiernie intrygujący $z$ perspektywy badacza kultury; inaczej też należałoby widzieć ksiażkę, gdzie figura ta pojawia się, czyli Pięknych dwudziestoletnich. Nie jest to „powiastka”, by użyć języka Chmielewskiego, lecz poważne i wcale niełatwe do jednoznacznego zaklasyfikowania dzieło. Jeśli przyjać taki punkt widzenia, to to, co zwykło się określać mianem "mitomanii” czy „kabotyństwa” Marka Hłaski zyskuje odmienną od dotychczas obowiąującej wymowę: Hłasko byłby zatem pisarzem dojrzałym (stał się nim bardzo szybko!), świadomym ponadto kulturowo uwarunkowanej autokreacyjnej funkcji literatury, pozy zaś, jakie przyjmował, miny, które robił sa/były niczym innym jak przejawem pisarskiej gry $z$ kultura, gry toczonej za pomocą środków samej kultury. Co więcej, twórczość Hłaskowską należy widzieć w kontekście przypadku pośród przypadków, objawiających w polskiej literaturze „prawdę zmyślona”, jak powiedziałby Marcin Kafar (por. w niniejszym tomie: 151$)^{2}$.

Aby zrozumieć zarysowany tutaj typ argumentacji, potrzeba specyficznej pracy myślowej, polegającej na podjęciu określonych tropów literaturoznawczych (np. poczynienia odniesień do koncepcji „paktu autobiograficznego”, czy wyłuszczenia problemu napięcia pomiędzy fikcją a rzeczywistością) oraz umiejscowieniu ich w horyzoncie kulturoznawczo-filozoficznym, umożliwiającym zobaczenie „starych” rzeczy w „nowym” świetle.

${ }^{2}$ Przychodzi mi na myśl choćby Ireneusz Iredyński. Łączy go z Markiem Hłaską bardzo wiele, dziwi więc, że brak szerszych omówień podobieństw i różnic obu tych pisarzy. Poza tym nie tylko Marek Hłasko zasłynął przecież z pozowanych fotografii (nie ma chyba zdjęcia, na którym by nie „grał”); pozował np. Witold Gombrowicz, a wśród pisarzy dzisiejszych znany jest $z$ tego Andrzej Stasiuk. 
Poniżej wyróżnię wstępnie cztery aspekty „prawdziwego zmyślenia". Nadmienię, iż w kulturowej praktyce pozostają one komplementarnymi, mnie natomiast posłużą do uchwycenia kluczowych aspektów osobistej historii, będącej punktem kulminacyjnym przedstawianego tekstu.

Pierwszy z nich dotyczy literatury, czy, wykładając sprawę precyzyjniej, funkcji literatury, rozumianej na sposób Hłaskowski. Literatura miałaby tu nobliwe zadanie, polegajace na mierzeniu się z rzeczywistościa, w przypadku Hłaski - rzeczywistościa ustroju totalitarnego. W opinii autora Sowy, córki piekarza literatura majaca ambicje mierzenia się $z$ rzeczywistością totalitarna, winna być właśnie „prawdziwym zmyśleniem”. Taki postulat wyrażany jest wprost w Pięknych dwudziestoletnich, a kryje się za nim przekonanie, iż socrealizm jest ustrojem fantastycznym, czysto surrealnym (por. Hłasko 1997: 154, 161, 180). W „prawdziwym zmyśleniu" tkwi więc świadoma strategia literacka, lecz jednocześnie jest to również strategia obcowania ze światem, wynikająca $z$ mocnego $z$ nim zrośnięcia. Dobrze oddaje to fragment wywiadu, gdzie Hłasko zaznacza swą sympatię do literatury amerykańskiej: „Oni [pisarze amerykańscy - przyp. M.R.] już nie szukają dla człowieka żadnego wyjścia, żadnego sensu życia, tylko w sposób uczciwy, niemalże dokumentarny, przekazują doświadczenia swego czasu, swojego życia. Ja tak nienawidze mitologii w literaturze, że zapewne ten typ prozy odpowiada mi w amerykańskiej literaturze. Poza tym sa to wspaniali ludzie. My tu wszyscy siedzimy w "Kameralnej" albo w "Kopciuszku", albo diabli wiedza gdzie, a oni żyją na swoich fermach i potrafią się cieszyć swoim własnym życiem, co jest w Polsce dotychczas sztuką nie znaną; mają swoje namiętności: rybołówstwo, polowanie, samochody. Sa to jacyś bardzo autentyczni ludzie, my zaś przecież wszyscy jesteśmy wymyśleni" (Badź wierny sobie... 1991: 189). Sformułowanie „wymyślenie” pojawia się także w artykule pt. Chwileczke, grabarze... (1991 [1958]); Hłasko twierdzi tam, inteligentnie odpierajac liczne, kierowane wobec niego zarzuty, że to nie on wymyślił taką Warszawę, jaka opisywał, lecz to ona wymyśliła jego (Tamże).

Osnucie Hłaskowskiej twórczości wokół wątku „prawdziwego zmyślenia" splata się $z$ doświadczeniem rozpołowienia biograficznego, pisania $z$ dystansu przestrzennego i czasowego o sprawach dotyczących komunistycznej Polski. Po wyjeździe za granicę, Marek Hłasko nie opisuje już żadnego innego kraju w taki sposób, jak czyni to w odniesieniu do Polski. W pisarstwie „pozapolskim” idzie jednak o coś dużo istotniejszego niż samą literaturę - cel określa 
konstruowanie zmyślonego obrazu siebie. Tym, co łączy kontekst doświadczenia ojczyzny i doświadczenia bycia poza nia jest tragizm totalnego wyobcowania (jak powiada Hłasko: „w jednej połowie jest nie do życia, a w drugiej nie do zniesienia" (cyt. za Stanisławczyk 1998: 54)), powiazanego $z$ dojmujacym poczuciem sztuczności i obcości świata zmierzającego do „cichego katastrofizmu”3. Hłaskowscy bohaterowie żyja w rzeczywistości pozbawionej fundamentów etycznych, które rozpadły się w XX wieku. Za słowami oraz ich referencyjnością (to jedna $z$ obsesji Hłaski) już nic nie stoi, można je zatem bezkarnie powtarzać - jak mówi Robert w Nawróconym $w$ Jaffie, zwracając się do Jakuba: „Nikt nie ma własnych słów. Wszyscy powtarzają te same świństwa od tysięcy lat. Czy nie rozumiesz, że gdyby Bóg naprawdę był, to my dwaj nie moglibyśmy żyć ani przez minutę?" (Hłasko 1993a: 196). Gdybym miał zwięźle określić, pod jaka regułę podpada twórczość Marka Hłaski, powiedziałbym, że to twórczość, w której słowa sa już tylko słowami, nie odnoszą się bowiem do rzeczywistości, sa zaledwie jej etykietkami.

Odpowiedzia podmiotu na ten fraktalny świat - by użyć $z$ rozmysłem terminu Jeana Baudrillarda (2009: 7-8) - jest przemyślana gra autokreacyjna, przejawiająca się w licznych pozach, służących obnażeniu sztuczności międzyludzkich konwencji. W takim świecie należy przyjąć rolę aktora wymyślającego, pozbawionego oczywistego scenariusza, wszelako przewidujaccego dla siebie samego potrójną funkcję: scenarzysty, reżysera i aktora. To nie wszystko, nie to jest najważniejsze, bo choć zakładamy maski, podczepiając się pod różne scenariusze, to w istocie poszukujemy własnej autentyczności, która spokrewniona jest $z$ wolnością. Czy to jest jednak możliwe? Czy świadome odgrywanie i decydowanie, jakie postacie chce się odgrywać, nie daja już pewnej wolności? Przeczuwam (podpowiada mi to moja intuicja), że właśnie w postawie „pozowania” zaznacza się wolność, na jaką człowiek w tamtych czasach mógł sobie pozwolić. Wykorzystuje się tu kostiumy, aby ocalić resztkę wolności w świecie niemal jej pozbawionym, pośrednio zyskując akceptację trudnego do pojęcia świata, z zastrzeżeniem: chcąc po-

${ }^{3}$ Posługuję się tutaj określeniem Jana Skoczyńskiego, dotyczącego twórczości Stanisława Witkiewicza (Skoczyński 2014: 64-81). Zwrot „cichy katastrofizm” dotyczy metamorfozy kultury europejskiej, szerzej - zachodniej, która wytraca swojego metafizycznego ducha, produkując tym samym „człowieka jednowymiarowego”. Marek Hłasko w liście do Agnieszki Osieckiej, będąc w Paryżu, napisał: „Rzygać mi się chce, patrząc na małość i nędzę tego świata; na tych embrionów w samochodach, na tę zorganizowana, wymoszczona i ułatwiona i ratalnie spłaconą drogą do śmierci” (cyt. za Stanisławczyk 1998: 53). 
zostać autentycznym, nawet jeśli się gra, trzeba samemu wybrać swą maskę, trzeba wiedzieć, że będzie się nią grać.

Co ciekawe, w przypadku Marka Hłaski „materiałem”, gdzie udaje się „pozować” jest nie tylko literatura, ale i życie pozatekstualne. Hłasko nie tylko pisze „prawdziwym zmyśleniem”, lecz wprowadza je w czyn, testuje na sobie błazeński kostium nadrealnej kultury, na co celnie wskazywał Adam Chmielewski (1993a: 62-63), który, niestety, pominą istotny dla tych praktyk wymiar.

Dochodzę tym samym do drugiego aspektu „prawdziwego zmyślenia", związanego $z$ zatarciem granicy między literatura a życiem. Wielu $z$ nas, piszących o życiu - to typowy haracz, jaki przychodzi płacić za zabawę w literaturę - wcześniej czy później nie jest w stanie rozstrzygnać, co jest prawda, co fałszem, a co „prawdziwym zmyśleniem" - to ostatnie sytuuje się poza prawda i poza fałszem. Można próbować wyobrazić sobie Marka Hłaskę odgrywającego "Marka Hłaskę", by zrozumieć, iż wykreowane przez siebie samego „życie” oparte jest na wziętej z literatury „zmyślonej prawdzie”. Idąc dalej: jeśli zdarza się, iż nie ma wielkiej różnicy pomiędzy życiem a literatura, a ta jest oparta na „prawdziwym zmyśleniu”, to takie również powinno być i realne życie, płynnie niekiedy przemieszczające się w sferę znajdujaca się poza prawdą i poza fałszem.

Osadzone na powyższych przesłankach „prawdziwe zmyślenie" traktuje jako projekt tożsamościowy, autokreacyjny, majacy oparcie w określonym kontekście społeczno-politycznym, którego sztuczność, a nawet opresyjność została bez ogródek obnażona przez Marka Hłaskę.

Owa autokreacja znakomicie ujawnia się m.in. w napisanych przez Hłaskę „autobiografiach”. „Autobiograficzni” są oczywiście Piękni dwudziestoletni, ale znamiona „autobiograficzności” nosi też kilka innych tekstów (przywołać wypada Drugie zabicie psa, $\mathrm{Na}$ wróconego w Jaffie, Sowę, córke piekarza), gdzie Hłasko-autor wydaje się być jednocześnie bohaterem opowieści. Występująca tam postać jest pod wieloma względami zbieżna $z$ powołującym ją do tekstowego „życia” autorem; bez wielkiego wysiłku zaczynamy więc wierzyć, że oto Hłasko pojawiający się w literackim „przebraniu”, opowiada po prostu własne, przeżyte i przez to prawdziwe historie.

Jeśli mowa o związku życia pisarza i jego „autobiografii”, czyli zapisu życia dokonanego przez siebie samego, to w naturalny sposób rodzi się skojarzenie $z$ „paktem autobiograficznym”. Przypomnę, iż określenie wprowadzone przez Philippe'a Lejeune'a oznacza - mówiąc najprościej - „tożsamość bohatera, narratora i autora, uzyskiwana między innymi poprzez charakter narracji oraz identyczność 
nazwiska $z$ okładki i w tekście" (Galant 1996: 99). W moim przekonaniu oryginalność Hłaskowskiego „paktu autobiograficznego” polega na jego parodii; do tego też sprowadza się istota metafory „prawdziwego zmyślenia” jeśli chodzi o drugi jej aspekt. Piękni dwudziestoletni stanowia parodię paktu autobiograficznego, a co za tym idzie, nie sa klasyczna autobiografia, lecz parodia autobiografii. Myśl taką odnajduję po części u samego Marka Hłaski, piszącego w liście do Matki, Marii Hłasko: „Jeśli nie umiesz czytać i nie rozumiesz różnicy pomiędzy parodia a autobiografia - cóż mogę ci powiedzieć, najlepiej nie czytaj” (cyt. za Stanisławczyk 1998: 178). Interesujące zdanie pojawia się dalej: „Gdybyś przeczytała uważnie, to dowiedziałbyś się wielu rzeczy. Między innymi kto nauczył mnie czytać i komu zawdzięczam miłość do książek" (Tamże: 178). Owszem, w owej usankcjonowanej odautorsko parodii autobiografii pojawiają się więc prawdziwe informacje, lecz sa i takie, które sa jawnie fałszywe. Piękni dwudziestoletni to ni mniej, ni więcej tylko „prawdziwe zmyślenie”, pole tekstualne, gdzie Hłasko tworzy siebie takiego, jakim chciałby być zapamiętany przez tych, dla których książa jest przeznaczona, a być może także takiego, jakim pragnął być dla siebie samego - człowieka niestrudzenie „zszywającego" życie z literaturą. Podaje więc autor Pięknych dwudziestoletnich zarówno fakty, jak i „fakty”, lepiąc $z$ nich opowieść o swoim życiu, jedynej historii mającej (dla niego) znaczenie. W tej opowieści nie występuje Marek Hłasko-pisarz-bohater, ale Marek Hłasko-pisarz-bohater-którego-nigdy-realnie-nie-było. Paradoksalnie, nie jest to istotne, gdyż Hłasko wie, że opowiadane o nim historie i tak nigdy nie powiedza, kim był naprawdę. Tak jakby chciał nam przekazać przesłanie: „Opowiadam Tobie-Czytelniku historię o samym sobie, która jednak nigdy nie miała miejsca poza moją wyobraźnią, ale która jest prawdziwa i, co więcej, w którą jesteś gotów uwierzyć, bo $z$ jakiś względów masz tendencję do zakładania "paktu autobiograficznego". Rozróżnienie na "realne” i „fikcyjne” zaciera się w praktykowaniu „prawdziwego zmyślenia”: biora w nim udział zarówno ci, co opowiadaja, jak i ci, co słuchaja, w podobnym stopniu podlegający zasadzie: „Aby zrozumieć moją opowieść musisz porzucić logikę ("prawdziwe zmyślenie» jest przecież paradoksem) i wejść w świat autokreacyjnej gry, która dla Ciebie-Czytelniku przygotowałem. Jeśli jej nie podejmiesz, nic nie zrozumiesz, będziesz jedynie ulegał iluzji i poszukiwał tego, kim byłem naprawdę".

Podkreślę: w zaprezentowanej przeze mnie perspektywie należy zrezygnować $z$ rozpatrywania postaci Marka Hłaski oraz jego „życia i dzieła" w kategoriach prawdy i fałszu, trzeba przestać dociekać, 
kiedy Marek Hłasko kłamie, zmyśla, konfabuluje, a kiedy mówi prawdę. Gdzieś pośrodku jest „prawdziwe zmyślenie” - tutaj równoważne kreacji własnego życia na wzór wzięty $z$ literatury. „Prawdziwe zmyślenie" jest w tym kontekście swego rodzaju pomostem pomiędzy „dziełem” a „życiem”. Żadnego $z$ nich nie powinno się traktować jako osobnych bytów, ergo różnych ontologii. Można by użyć jeszcze innej metaforyki: życie jest laboratorium dla literatury, literatura zaś dla życia, przy czym granica w obu przypadkach pozostaje bardzo nieostra. W pewnym sensie literatura Marka Hłaski nie odbiega od jego życia, widać wyraźnie jakąś próbę upodobnienia jednego do drugiego, choć nie bardzo wiadomo, co miałoby być tu pierwowzorem: twórczość czy życie (a właściwie dlaczego mamy szukać tego pierwowzoru?).

Tak zarysowany kontekst interpretacyjny niesie za soba poważną konsekwencję: nie interesuje mnie „prawdziwa” prawda o Marku Hłasce. Zdaję sobie sprawę $z$ kontrowersyjności takiego podejścia, lecz uważam, że nie ma innej o nim prawdy, niż ta zawarta w jego książkach. Stosując taki zabieg, pozostaję wierny autorowi Nawróconego w Jaffie. W Pięknych dwudziestoletnich oraz Sowie, córce piekarza, Hłasko powtarza - jakby chciał mieć pewność, że czytelnik dobrze to zapamięta - kilka wariantów stwierdzenia: „Życie, które mi dano jest tylko opowieścią; ale jak ja ja opowiem, to już moja sprawa. Jedynie o to mi chodzi" (Hłasko 1997: 47), albo: „Dano ci życie, które jest tylko opowieścia; ale to już twoja sprawa, jak ty ja opowiesz i czy umrzesz pełen dni" (Hłasko 1993b: 126) ${ }^{4}$.

${ }^{4}$ Poczynię w tym miejscu dygresję osobistą. Otóż, moja praca magisterska poświęcona narracjom śmierci (patrz Rydlewski 2007a), uświadomiła mi (myślę, że Marek Hłasko świetnie by to zrozumiał), że nie ma po prostu takiej prawdy, czy może inaczej - nie da się do niej dotrzeć, bo opowiadane o kimś opowieści sa zawsze posadowione w różnych kontekstach, opowiadają je różni ludzie różnym ludziom, co czyni je niewspółmiernymi względem siebie. Uchwycenie „prawdy” o życiu drugiego człowieka, jakiejś prawdy „w ogóle” jest niemożliwe. Ona zawsze będzie perspektywiczna i cząstkowa. Wniosek taki wysuwam na podstawie własnych badań terenowych, prowadzonych w najtrudniejszym $z$ trudnych terenów, tj. w swojej Rodzinie. Żałuję ogromnie, że nigdy nie udało mi się napisać artykułu przedstawiajacego wyniki tych badań oraz opowiedzieć o szeregu doświadczeń $z$ nimi zwiazanych, łacznie $z$ osobistymi konsekwencjami, do jakich one prowadziły. W perspektywie „prawdziwego zmyślenia” poruszyłbym tutaj następujaca kwestię (mająca już swoje miejsce w literaturze antropologicznej), mianowicie, osoba opowiadajacca nie jest wolna od kreacji samej siebie, niekiedy nawet od opowiadania zmyślonych rzeczy (a „przyłapałem” na tym jednego z moich terenowych interlokutorów); jako badacz nie traktowałem jednak tej wypowiedzi jako kłamstwa, ale właśnie jako część „prawdziwego zmyślenia”, opowiadania, którego sens 
Badacze zajmujący się postacią Marka Hłaski, usilnie próbują dowieść, kim on był „naprawdę” - bez literackiej maski. Dla przykładu, Piotr Wasilewski pisze we wstępie swojej książki: „Tom "Śladami Marka Hłaski» jest próbą zbliżenia się do prawdy o Nim, w miarę dostępnych informacji i możliwości" (Wasilewski 1994: 8). $Z$ kolei Danuta Kalinowska ma nadzieję, na „ukazanie faktycznego obrazu Marka Hłaski - człowieka i pisarza” (Kalinowska 2000: 45). Adam Chmielewski mówi natomiast: „Zobaczyłem go bez literackiej maski" (Czytamy w Polsce... 2011).

Jako że przywołani autorzy nie znali pisarza osobiście (choć nie wiem, czy i to by nas przybliżyło do owej pożądanej „prawdy”), bazują więc na tym, co on sam pisał i mówił o sobie oraz na tym, co pisali i mówili o nim inni. Niekiedy Wasilewski, Kalinowska i Chmielewski dokonuja „zestawien” porównawczych, kompilujac autonarracje Hłaskowskie $z$ opowieściami „naocznych” świadków zdarzeń, w których Hłasko brał udział; wyłaniająca się tutaj wielowariantowość przekazu może dziwić tylko wówczas, gdy przyjmiemy, że rzeczywista rzeczywistość (realne życie) i opowieść o niej sa tożsame. Sytuacja zmienia się diametralnie od chwili zyskania świadomości, że Hłasko „chodzi i opowiada”, opowiada różne rzeczy, które nie sa kłamstwem, tylko szlifowaniem opowieści-siebie samego.

Trzeci $z$ aspektów „prawdziwego zmyślenia” wiąże się $z$ filozofią podmiotu, przebijająca $z$ książek i biografii Hłaskowskiej, jednakże, niejako równolegle, istniejącej w silnym oderwaniu od prawdziwego człowieka: chodzi więc o figurę myślową, stanowiącą tożsamościowy fantazmat.

Czwarty aspekt sprawy dotyczy typu kultury, w jakiej zakorzeniony jest ów podmiot. Zasadne jest w zwiąku $z$ tym np. rozważenie problemu, na ile wspomniana filozofia podmiotu jest aktualna, albo, mówiąc inaczej: czy metafora "prawdziwego zmyślenia” przydatna jest w odniesieniu do badania kultury współczesnej? Uważam, że kwestie takie jak: odgrywanie zachowań innych ludzi, powtarzanie słów, gestów, opowieści, i - co najważniejsze - zatarcie się w dużej mierze granicy pomiędzy „sztucznym” a „autentycznym", może być rozpatrywane przez teoretyka kultury jako zwrócenie uwagi na niebagatelny aspekt „pracy” kultury, m.in. w zakresie

wymyka się prostemu podziałowi na prawdę i fałsz. Albo inaczej: to kłamstwo, nie do końca nawet wiem, czy uświadamiane, było znaczące i wiele mówiło badaczowi. Ostateczny wniosek, do jakiego doszedłem jest następujący: nie można uchwycić prawdy o drugim człowieku, zmarłym członku Rodziny, można jednie wysłuchiwać i żyć opowieściami o nim. 
uznawania sztucznych konwencji za własne. W szczególnie kłopotliwej sytuacji stawia to podmiot autorefleksyjny $-z$ jednej strony znajaccy mechanizmy pracy kultury, $z$ drugiej, majacy jasność, iż niekiedy staja one $\mathrm{w}$ konflikcie $z$ poczuciem autentyczności. Jak pokażę niżej, kłopot o takim zabarwieniu nie ominął i mnie samego.

\section{Rzecz o poczuciu antropologicznej nieautentyczności}

Przyszła pora, abym zdradził Czytelnikowi, skąd wzięło się moje nastawienie, dzięki któremu, najprawdopodobniej, w ogóle odkryłem metaforę „prawdziwego zmyślenia”. Pozostając w klimacie Hłaskowskim, posłużę się opowieścią, przeplataną autorefleksyjnymi komentarzami.

Kilka lat temu byłem studentem etnologii oraz filozofii (której - ze względu na to, że jeśli nie pojawiała się mowa o kulturze, śmiertelnie mnie nudziła - nigdy nie skończyłem) na Uniwersytecie Mikołaja Kopernika w Toruniu. Przechodziłem właśnie antropologiczny obrzęd przejścia, polegający mniej więcej na tym, iż wszystko to, co wydaje się „naturalne”, oczywiste, zwykłe, potoczne, należące do świata „samego w sobie”, staje się „kulturowe". Ów rite de passage oraz specyficzna faza kryzysu, w jakiej tkwiła wówczas etnologia (Rydlewski 2006: 35-49) sprawił, że zaczęła mnie zajmować tylko jedna prawdziwie egzotyczna kultura - moja własna, a pośród niej ja sam jako podmiot wyobcowany. Wiadomo, iż to intelektualny świat zachodnio-europejski wymyślił antropologiczne pojęcie kultury oraz dyskurs antropologiczny jako taki, czyniąc ich wyróżnikami przymus stawania się relatywistą (uważam, że nie można uprawiać tej dziedziny wiedzy nie będąc nim choć trochę) oraz nawyk ciagłego relatywizowania statusu własnych przekonań. Dzięki obrzędowi utraty kulturowej „niewinności” stawałem się - jak trafie ujęła to Dorota Angutek - „antropologiem-outsiderem”, „którego cechuje już nie tylko dystans wobec własnej kultury i tolerancja kultur obcych - takimi byli uczniowie Boasa - ale skrajne, celowe wyobcowanie $z$ własnej kultury i dzięki temu, spoglądanie na nią m.in. w sposób nadrealistyczny" (Angutek 2006: 218). Dla takiego typu antropologa, antropologa patrzącego na świat własnej kultury z zewnątrz, wszystko jest potencjalnie „obce” i „dziwaczne”. „Z jego niepowtarzalnej pozycji zewnętrznego obserwatora, wszystko wydaje się 
wyrazistsze - powiada Angutek. (...) Otaczający go tzw. zwykły świat, to prawdziwy "świat dziwów" (Tamże). Nadmienię na marginesie, że świadectwo tamtej osobistej przemiany świadomości stanowia dwa artykuły, poświęcone antropologii współczesności (patrz Rydlewski 2006: 35-49, 2007b: 287-294); napisałem je nieco później, będąc już studentem studiów II stopnia, tym razem na Uniwersytecie Warszawskim, gdzie kontynuowałem kurs etnologii. Nie wiem, czy wspomniane teksty sa udane, na pewno jednak oddaja moja fascynacje tym, co stopniowo odkrywałem na temat najbliższego mi kulturowo świata i mojego w nim miejsca.

Wracając do Torunia... pamiętam, że po którymś $z$ wykładów ze współczesnej filozofii kultury, podszedłem do prowadzącego je profesora Andrzeja Szahaja i poprosiłem o udzielenie mi wywiadu. $\mathrm{Ku}$ mojemu zaskoczeniu, profesor zgodził się na rozmowę. Dotyczyła ona teorii i historii kultury oraz konstruktywizmu społecznego. W pewnym momencie, profesor wypowiedział kluczowe dla mnie słowa: „(...) wiedza na temat swojego własnego skonstruowania czyni nas mądrzejszymi, lecz nie zawsze szczęśliwszymi” (Rydlewski, Szahaj 2005: 7). Wtedy nie do końca rozumiałem kryjące się za tym stwierdzeniem przesłanie, nic dziwnego, hasła takie jak „konstruktywizm”, „etnologia”, „relatywizm” były dla mnie wówczas romantyczna przygoda, a odkrywanie konwencjonalności świata oznaczało podróż w nieznane. Ponadto - „antropolog-outsider” nie czuje się przecież nieszczęśliwy! On jest intelektualnie podniecony egzotycznością swojego świata!

Chyba dopiero na początku studiów doktoranckich (rozpocząłem je w pod kierunkiem profesora Szahaja w roku 2008) do końca pojąłem, że antropologiczna czy konstruktywistyczna droga, jaka przechodzi podmiot (przemieszczając się od przekonań „milcząco” respektowanych do swiadomie akceptowanych), powoduje utratę naturalności bycia-w-świecie; zdałem sobie sprawę, że Andrzej Szahaj miał rację mówiąc, iż wiedza na temat swojego własnego skonstruowania jest faktycznie niebezpieczna, albowiem - o to w gruncie rzeczy tutaj idzie - może ona dalece skomplikować życie, czyniąc z uczestnika wydarzeń obserwatora - wciąż reflektujący podmiot, a nie kogoś przeżywającego dane sytuacje. Próbowałem sobie jakoś z tym poczuciem „wymyślenia” bądź „uJarzmienia” mnie przez kulturę - jak powiedziałby Foucault - poradzić. O ile wcześniej, jako antropolog-outsider, patrzyłem na "egzotyczna” kulturę, o tyle teraz „egzotyczny” stał się sam patrzacy (dylemat ten próbowałem rozważyć w artykule pt. Samoświadomość a gładkość funkcjonowania $w$ kulturze (Rydlewski 2010: 66-77)). 
Użyte przeze mnie słowo „nieautentyczność” wymaga poczynienia dodatkowego komentarza. W perspektywie konstruktywistycznej moje „ja” jest uwarunkowane przez wspólnoty interpretacyjne, do których należę. Nie ma żadnego „ja” transcendentalnego, trudno bowiem powiedzieć, czym miałoby być owo „ja” poza oryginalnym splotem okoliczności społecznych (wypadkowo oryginalnego skrzyżowania się wspólnot, do których jednostka należy). Tylko „naiwny" filozof może wierzyć, że dokonując jakiegoś fenomenologicznego epoche dotrze do tego „ja” (bo niby jak wykonać gest anulujacy to, co właśnie jednostkę tworzy?). A zatem wszystko co myślę, co widzę i odczuwam zostało mi zaszczepione, w tym sensie nie jest moje, lecz wspólnot/wspólnoty, do których/której należę. Nie ma nic „czysto” prywatnego, tak jak nie może być prywatnego języka. Piszac te słowa nie staram się dokopywać się tego, co pod kultura jest (nawiasem mówiąc, cóż miałoby to być? Moja biologiczna natura? Odpowiedź na to pytanie pozostawiam „naiwnym” biologom...). Chodzi mi raczej o to, aby na gruncie kultury (akceptując myśl, że nie ma nic poza nia) powiedzieć coś od siebie, wypowiedzieć coś, czego nie wypowiedział jeszcze nikt inny (w końcu zawsze ktoś jest pierwszy, co w interpretacji konstruktywistycznej oznacza, że ktoś taki posiada duże kompetencje kulturowe w ujawnianiu „milczących” przekonań) (Rydlewski 2015). W perspektywie konstruktywistycznej można przyjąć, że tak długo jesteśmy autentyczni (tak nam się przynajmniej wydaje), jak długo wypowiadane słowa uważamy za własne, a nie wspólnoty, do której należymy, dopóki nie wiemy, że to nie sa nasze własne słowa. Brak tej wiedzy czyni nas szczęśliwszymi - tak ująłby to Andrzej Szahaj. Problem, który się tutaj pojawia, da się ująć następująco: jeśli nie ma innego wyjścia (a w perspektywie konstruktywizmu nie ma) i jesteśmy stworzeni przez kulturę, to po co się tym przejmujesz? Jeśli to nie ty mówisz, ale jesteś mówiony przez swoją wspólnotę, a jej przekonania sa twoimi przekonaniami, to po co robisz $z$ tego problem? Otóż, nie wiem. Nie znam odpowiedzi na te pytania. Nie znajduję żadnego uzasadnienia, dlaczego czuję się nieautentyczny (musi być pewnie jakieś milczące przekonanie związane $z$ poczuciem oryginalności, którego nie mam na talerzu). Nawiasem mówiąc, w starszych latach szkoły podstawowej, wraz z moimi kolegami potrafiliśmy rozmawiać tylko tekstami $z$ filmów i seriali Stanisława Barei (umiemy to $z$ reszta do teraz) i wcale nam to nie przeszkadzało, że to sa nie nasze słowa. Czyżby więc antropologiczna/konstruktywistyczna edukacja na poziomie akademickim komplikowała tę kwestię? Co się we mnie zmieniło, że używanie cudzych słów powoduje, że nie 
czuję się autentyczny, choć kiedyś tak nie było? Pozostawiam ten problem z zakresu filozofii podmiotu otwartym.

Jak sugerowałem wyżej, ciepło zapatruję się na projekt „antropologa-outsidera", zaryzykowałbym nawet wyznanie, że jestem kimś, kogo charakteryzuje Dorota Angutek. Spoglądając wstecz sądzę, że na początku mojego dojrzewania akademickiego byłem zaintrygowany kultura jako czymś egzotycznym, a potem stałem się kimś, kto wie o swoim uwikłaniu w tęże kulturę i, pomimo fascynacji nia, czuje się tożsamościowo „dziwnie” (nie-swojsko), choć nie podpada pod figure "egzystencjalnego nihilisty” (właśnie dzięki świadomości istnienia kultury, która mu to uniemożliwia - w perspektywie konstruktywizmu bardzo trudno być nihilista).

Artykuł pt. Samoświadomość a gładkość funkcjonowania w kulturze przygotowałem na potrzeby wystapienia $z$ okazji pierwszego sympozjum konstruktywistycznego we Wrocławiu ${ }^{5}$. Tekstu tego nikt chyba nie odebrał tak, jak o nim pierwotnie myślałem, co pewnie wynikało $z$ faktu, że wielu konstruktywistów obecnych na zjeździe nie było już konstruktywistami społecznymi. Być może tylko profesor Andrzej Zybertowicz zrozumiał mój dylemat. Jego komentarz był oryginalny (jak zwykle...); profesor po prostu położył na stole swój telefon komórkowy i odtworzył z niej znana piosenkę nakazująca cieszyć się życiem: „In the summer time, when the weather is fine...". Nagle przestałem się łudzić, że nauka (przynajmniej w jej obecnym kształcie) pomoże mi rozwiązać moją zagwozdkę. W sztuce ratunek - pomyślałem - to przecież ona jako pierwsza przeszła proces „odczarowania”, zyskując samoświadomość swoich konwencji. Bliski był mi w tym kontekście surrealizm etnograficzny, ale on raczej pozostawał po stronie radosnego „antropologa-outsidera", ceniłem także genialny film Tomasza Zygadły pt. Ćma (kapitalnie pokazujący nazbyt autorefleksyjny podmiot i konsekwencje, do jakich prowadzi zbyt duża "porcja” wiedzy o świecie, w którym się żyje) oraz Mniejsze niebo w reżyserii Janusza Morgensterna, i...

\section{...wtedy...}

I wtedy do głowy przyszedł mi czytany już w szkole podstawowej i liceum Marek Hłasko. Teksty Hłaski znałem na pamięć (obudzony w środku nocy potrafię mówić kwestiami z Drugiego zabicia

${ }^{5}$ Odbyło się ono 14-15 października 2009 roku. 
psa). Sięgnąłem po Sowę, córkę piekarza i odnalazłem fragment, gdzie główny bohater-narrator, Grzegorz (vel Hłasko?6), spotyka $\mathrm{w}$ pociagu dopiero co wypuszczonego $z$ komunistycznego więzienia lotnika. Toczy się rozmowa, nieznajomi opowiadaja sobie historie, a te przenika obopólna zgoda na podejmowana grę: „Moja chora małpa zamilkła nagle [tak Grzegorz-Hłasko w myślach nazwał lotnika - przyp. M.R.]. Zamilkł był, gdyż musiał; i nawet w ciagu tych siedmiu lat spędzonych w więzieniu nie zapomniał, że ludzie występujący w filmach milkna, kiedy zadaje im się decydujące pytanie, i wpatrują się ponuro w złota szczękę reżysera. Myślałem, że moja chora małpa była teraz gościem, który nazywał się Humphrey Bogart; tak myślałem, ponieważ i ja sam często bywałem Bogartem. Bogie zawsze milczał, trzymając owłosiona łapę na szklance whisky, a uśmiechał się tylko wtedy, kiedy widział wycelowany $\mathrm{w}$ siebie rewolwer.

- Strzelaj - powiedziałem. - Oddasz mi tylko przysługę.

- Proszę?

- Bogie tak zawsze mówił - powiedziałem. - I wtedy podnosił szklankę do ust, a nigger siedzący przy fortepianie mówił: "Dosyć pan już pił tej nocy, szefie».

Chodzi tylko o to, aby życie toczyło się jakoś naprzód przy pozorach dramatyzmu. I tylko o to" (Hłasko 1993b: 21).

To było to! Wróciłem do Marka Hłaski z nowym pytaniem. Szukałem u niego odpowiedzi, jak żyć z poczuciem swojego własnego „wymyślenia”? Jak, pomimo sztuczności słów wypowiedzianych przez innych, powiedzieć coś szczerze i naprawdę? Ten dylemat - znakomicie wytropił go Jan Galant (1996: 72-77) - dręczy przecież wielu bohaterów Hłaski, niezwykle wrażliwych na „prywatne”, zarezerwowane tylko dla siebie teksty. Dobrym tego przykładem jest opowiadanie pt. Śliczna dziewczyna. Abakarow w Brudnych czynach mówi: „Nie umiem jej niczego powiedzieć, chociaż powinienem. Jestem jej winien jakąś ilość porządnych słów, tak jak jeden człowiek bywa drugiemu winien pieniądze, ale nie znam ich. Nie znam ani jednego $z$ nich" (Hłasko 1989: 395). Z kolei Robert w Drugim zabiciu psa przemienia autentyczne słowa wypowiadane przez Jakuba w teksty w „odstawianym” przez nich teatrze; ocenia je wyłączenie ze względu na to czy sa "dobre” - czytaj: czy nadadza się do prowadzonej gry. W Nawróconym $w$ Jaffie, będącym w istocie wariantem Drugiego zabicia psa (jego kapitalnym powtórzeniem!),

${ }^{6}$ Wedle Marii Hłasko, Sowa, córka piekarza to najbardziej autobiograficzna powieść jej syna. 
Robert stwierdza, że wszyscy mówimy cytatami, dlatego tak trudno rozpoznać, kiedy słowa sa prawdziwe, a kiedy sa tylko elementami wypełniającymi teksty („Nikt nie ma własnych słów. Wszyscy powtarzaja te same świństwa od tysięcy lat" (Hłasko 1993a: 196)). Jakub daremnie stara się walczyć o swoje własne słowa, co dobrze oddaje skierowane do Roberta pytanie: „Nie przyszło ci nigdy do głowy, że to moga być moje własne słowa?"7. Nawet wtedy, gdy Jakub, bez uzgodnienia $z$ Robertem, ujawnia Mary prawdę o inscenizowanym przez nich teatrze, ta bierze to za fałsz, a znowu Robert wplata słowa Jakuba w ustalony scenariusz - tym samym prawda przechodzi na stronę przedstawienia, zamieniając się w "prawdę" - jawnie teatralny przejaw istnienia.

Wspominałem o towarzyszącym mi poczuciu bycia wymyślonym przez kulturę w jej antropologiczno-konstruktywistycznym kształcie, Hłasko natomiast mówi o konkretnych innych (bardzo wyraźnie ich wskazuje), od których zapożycza dla siebie i swoich bohaterów słowa i gesty. To udawanie znajduje swój wyraz w przeistaczaniu się w szereg postaci, $\mathrm{np}$. w Sowie, córce piekarza ${ }^{8} \mathrm{w}$ majora, w Drugim zabiciu psa w oszusta matrymonialnego (jak byśmy to ujęli za pomoca współczesnej nowomowy).

Przywołam jeszcze i takie, świetnie dopełniające Hłaskowskie intuicje, skojarzenie. W filmie pt. Alpy w reżyserii Giorgosa Lanthimosa, grupa ludzi (dwie kobiety i dwóch mężczyzn), wciela się - na życzenie bliskich - w role zmarłych ludzi. Zgodnie $z$ instrukcjami dawanymi przez „pracodawców”, odtwarzają oni sceny z życia codziennego, momenty dramatyczne itp. Udaja kogoś, kim nie sa, działajac pod szyldem „Alpy” (bo ponoć „alpejskich szczytów nie da się zastąpić innymi górami”). Anita Piotrowska w recenzji tego filmu napisała: „(...) każdy $z$ nas jest tylko wiązką upodobań i nawyków, garścią rekwizytów, litanią charakterystycznych tekstów. Gdyby to wszystko odtworzyć, wyuczyć się tego na pamięć, oka-

7 Powtarzam je za przedstawieniem telewizyjnym pt. Drugie zabicie psa. Moim zdaniem zawiera się w nim kwintesencja dialogu Jakuba $z$ Robertem, zamieszczonego w Nawróconym w Jaffie (Hłasko 1993a: 191).

8 Zawsze intrygował mnie tytuł tej ksiązki, który pochodzi z Szekspirowskiego Hamleta. „Mówia, że sowa była córka piekarza” - to słowa Ofelii świadczące o jej szaleństwie. Ofelia popada w obłęd, kiedy już nie może udźwignąć ciężaru winy ani pojąć tego, co się wokół niej dzieje. Ofelia jest młodą dziewczyną, córką królewskiego dostojnika, zakochaną w księciu Hamlecie. Jej świat jest prosty - zakłada, że ludzie są dobrzy, a miłość szlachetna. Przyszłość widzi w jasnych barwach. Jednak taka wizja rzeczywistości musi w końcu legnąc w gruzach. Ufna Ofelia zmuszona jest do kłamstw i udawania. 
załoby się, że nie ma ludzi niezastąpionych...". Ta sama autorka zastanawia się, „jaki jest prawdziwy sens organizowanych w "Alpach" przedstawień? Czy mamy uznać je za oryginalna, choć tak naprawdę przecież oszukańcza, formę terapii? A może potrzebuja jej nie tylko ci, którzy stracili swoich bliskich? Jaka jest w tym wszystkim prawdziwa rola wynajętych "aktorów"? Jaką stratę sami sobie rekompensują? Dlaczego, jak w pewnym momencie filmu, wola żyć życiem pożyczonym? Dlaczego tak walcza między soba o role i ucza się ich $z$ takim morderczym wysiłkiem?" (Piotrowska 2012: 34).

Moim zdaniem Marek Hłasko kapitalnie - choć nie wprost rozstrzygną te kwestie; znakomicie rozpoznał pewien rys współczesnej kultury, w której mamy coraz więcej samowiedzy o swoich przekonaniach. Jak celnie podpowiada Jan Galant (1996: 85): „Gry prowadzone przez bohaterów opowiadań Hłaski opieraja się na stylizacji, naśladowaniu słów, zachowań, gestów zaczerpniętych $z$ dorobku kultury współczesnej i odznaczają się monotonna schematycznościa. Wzorzec stylistyczny stanowi bowiem pewna kalkę. Model bez końca powielany przez bohaterów. Ich zdolność do utożsamienia się $z$ rolą doprowadza do utraty kontroli - nie wiedzą już, co stanowi ich własność, a co jest zapożyczeniem". W jednej ze scen w Palcie ryż każdego dnia, na pytanie, czy naprawdę wierzysz, że nie ma ludzi niezastapionych(?), bohater (vel Hłasko?) odpowiada przecząco. Co zatem świadczy o wyjątkowości człowieka? Według mnie - jego własna opowieść lub, lepiej byłoby rzec, jego własne opowiadanie, gdyż „̇̇ycie jest tylko opowieścia idioty pełna wściekłości i wrzasku i nic nie znaczacą, która jest poza prawda i fałszem. Gdy w Pięknych dwudziestoletnich Artur Sandauer próbuje dociec, do czego zmierza Hłasko-opowiadacz, ten $z$ rozbrajająca szczerością wyznaje: „Nie wiem; o to właśnie chodzi, że nie wiem. Wiem tylko, że będę biegł przez całą drogę; i że będę mówił przez cały czas" (Hłasko 1997: 26). Nie wiem, czy Marek Hłasko odkrył w końcu, dokad zmierza, czy odnalazł swoja opowieść. Wiem jednak, że „zaufał swojemu szaleństwu”, był wierny sobie. A jak być wiernym sobie po odebraniu antropologiczno-konstruktywistycznego szlifu? To pytanie wciąż pozostaje dla mnie otwarte. 


\section{Bibliografia}

Angutek D.

2006 Kontrowersyjny wybór w obliczu współczesności, [w:] M. Brocki, K. Górny, W. Kuligowski (red.), Kultura profesjonalna etnolo-

Baudrillard J. gów w Polsce, Wrocław, s. 215-223.

2009 Przejrzystość zła, przeł. S. Królak, Warszawa.

Badź wierny sobie...

Bąź wierny sobie... Rozmowa z Markiem Hłasko w audycji „Muzyka i aktualności”, emisja 14.02.1958 Polskie Radio, zapis rozmowy znajduje się [w:] Hłasko nieznany, szkic wstępny i oprac. P. Wa-

Chmielewski A. silewski, Kraków, 1991, s. 189-190.

1993a Spotkania z Markiem Hłasko (1), „Odra”, nr 7-8, s. 62-69.

1993b Spotkania z Markiem Hłasko (2), „Odra”, nr 9, s. 73-79.

Czytamy w Polsce...

2011 Czytamy $w$ Polsce historie o wolności $i$ odwadze (wywiad Beaty Maciejewskiej $z$ Adamem Chmielewskim; tekst dostępny pod adresem: http://wroclaw.wyborcza.pl/wroclaw/1,35751,9792423,Czytamy_w_Polsce_Historie_o_wolnosci_i_odwadze.html; data dostępu: 11.10.2015).

Fish S.

2002 Interpretacja, retoryka, polityka: eseje wybrane, A. Szahaj (red.), przeł. K. Abriszewski i in., Kraków.

Galant J.

1996 Marek Hłasko, Poznań.

Gurczyńska-Sady K.

2013 Człowiek jako słowo $i$ ciało: $w$ poszukiwaniu nowej koncepcji podmiotu, Kraków.

Hłasko M.

1958 Chwileczke, grabarze..., „Kultura”, nr 6. Przedruk [w:] Hłasko nieznany, szkic wstępny i oprac. P. Wasilewski, Kraków, 1991, s. 196-201.

1989 Brudne czyny, [w:] M. Hłasko, Utwory wybrane, t. 3, wstęp L. Kurpiewski, wybór M. Komar, L. Kurpiewski, Warszawa, s. 149-176.

1993a Nawrócony w Jaffie, Warszawa.

1993b Sowa córka piekarza, Warszawa.

1997 Piękni dwudziestoletni, Warszawa.

1998 Mordercy sa wśród nas, Warszawa.

Kalinowska D.

2000 Marek Hłasko. Młody gniewny, Warszawa.

Nowicki W.

2012 Chwała półkownikom, „Książki. Magazyn do czytania”, dodatek do „Gazety Wyborczej”, grudzień, s. 64-66. 
Piotrowska A.

2012 Na szczytach absurdu, „Tygodnik Powszechny”, 26 sierpnia, s. 34.

Rydlewski M.

2006 Etnografie nieprzezroczyste i sztuka interpretacji. Wędrówki po antropologicznych narracjach, „Etnografia Polska”, t. 50, z. 1-2, s. 35-49.

2007a „Był człowiek $i$ nie ma człowieka...”. Percepcja nagłej śmierci $w$ narracjach rodzinnych (skrypt niepublikowanej pracy magisterskiej; dostęp: Biblioteka Uniwersytetu Warszawskiego).

2007b Docenione dziedzictwo, czyli surrealizm etnograficzny dzisiaj, „Polska Sztuka Ludowa. Konteksty”, nr 3-4, s. 287-294.

2010 Samoświadomość a gładkość funkcjonowania w kulturze, [w:] M. Kasprowicz, S. Drelich, M. Kopyciński (red.), Zjawisko szaleństwa w kulturze, Toruń, s. 66-77.

2015 Co czyni nas twórczymi? Różne kolektywy myślowe - różne "kręgi obcości». Przykład biografii Ludwika Flecka, „Archiwum Emigracji”, tekst w druku.

Rydlewski M., Szahaj A.

2005 Nauki o kulturze to nauki podstawowe. Wywiad z prof. dr. hab. Andrzejem Szahajem, „Etnografia Polska”, t. 49, z. 1- 2, s. 5-15.

Skoczyński J.

2014 Cichy katastrofizm czyli metamorfoza kultury europejskiej według Witkacego [w:] M. Rydlewski, R. Wiśniewski (red.), Filozoficzna refleksja nad kultura. Polska humanistyka pierwszej

Stanisławczyk B. połowy XX wieku, Toruń, 2014, s. 64-81.

1998 Miłosne gry Marka Hłaski, Warszawa.

Wasilewski P.

1994 Śladami Marka Hłaski, Kraków.

Wittgenstein L.

2011 Dociekania filozoficzne, przeł. B. Wolniewicz, Warszawa. 